Jurnal Caraka Prabu | Volume 01 | No. 01 | Juni 2017

\title{
PENYELENGGARAAN PENGATURAN PENANAMAN MODAL PEMERINTAH PROVINSI JAWA BARAT
}

\author{
Waluyo Zulfikar 1) \\ 1)Prodi Ilmu Administrasi Negara Universitas Nurtanio Bandung, Indonesia
}

\begin{abstract}
Abstrak
Permasalahan penyelenggaraan pengaturan penanaman modal di pemerintah provinsi Jawa Barat harus dapat diatasi dan diselenggarakan secara baik kepada masyarakat. namun pada penerapannya, penyelenggaraan pengaturan penanaman modal berdasarkan data di lapangan masih belum berjalan optimal, Kondisi tersebut justru menjauhkan konsep pengaturan penanaman modal dari konsep ideal, Aturan baku mengenai kelembagaan dan wewenang Dinas Penanaman Modal dan Pelayanan Terpadu Satu Pintu menjadi pemicu berbagai permasalahan dalam proses penanaman modal yang ada di wilayah provinsi Jawa Barat. Peneliti melakukan analisis secara mendalam dengan menggunakan metode analisis deskriptif kualitatif dimana hasil penelitian ini menyimpulkan bahwa keberadaan Peraturan Daerah tentang Penanaman Modal di Provinsi Jawa Barat merupakan landasan hukum bagi Pemerintah provinsi Jawa Barat dalam melakukan upaya mensejahterakan khususnya di bidang Penanaman Modal. Sedangkan untuk masyarakat atau badan hukum dengan adanya Perda tersebut lebih kuat mendapatkan kepastian hukum dalam malaksanakan kegiatan di bidang Penanaman Modal hasil penelitian ini merekomendasikan kepada Pemerintah Daerah dan/atau unsur legislatif baik secara bersama maupun sendiri-sendiri berkewajiban untuk segera menyusun Rancangan Peraturan Daerah tentang Penanaman Modal di Provinsi Jawa Barat sebagai wujud pemberian perlindungan hukum dan kesejahteraan bagi masyarakat dan sebagai amanat perundangudangan.
\end{abstract}

Kata Kunci: Perizinan, Penanaman Modal, Provinsi Jawa Barat

\begin{abstract}
The problem of this research is explore implementing investment arrangements in West Java provincial government must be resolved and implemented properly to the community. However, in practice, the implementation of investment regulation based on data in the field is still not running optimally, this condition actually keeps the concept of investment regulation away from the ideal concept, the standard rules regarding the institution and authority of the One Stop Investment Service and Integrated Services have triggered various problems in the investment process existing capital in the province of West Java. The researcher conducted an in-depth analysis using a qualitative descriptive analysis method where the results of this study concluded that the existence of the Regional Regulation on Investment in West Java Province is a legal basis for the West Java Provincial Government in making efforts to prosper, especially in the field of investment. As for the public or legal entities, with the existence of this regional regulation it is stronger to obtain legal certainty in carrying out activities in the field of investment. The results of this study recommend that the Regional Government and / or legislative elements both jointly and individually are obliged to immediately compile a Draft Regional
\end{abstract}


Regulation on Planting. Capital in West Java Province is a form of providing legal protection and welfare for the community and as a statutory mandate.

Keywords: Licensing, Investment, West Java Province

\section{PENDAHULUAN}

\section{Latar Belakang}

Persaingan global dalam perekonomian dunia saat ini semakin ketat, apalagi belakangan muncul Masyarakat Ekonomi Asean (MEA) yang akan diberlakukan pada akhir tahun 2015. MEA merupakan istilah lain dari pembentukan pasar tunggal di Asia Tenggara yang memungkinkan satu negara menjual barang dan jasa dengan mudah ke negara-negara lain di seluruh Asia Tenggara sehingga kompetisi akan semakin ketat. Karena itu, kebijakan penanaman modal harus diarahkan untuk menciptakan daya saing perekonomian nasional yang mendorong integrasi perekonomian Indonesia menuju ekonomi global. Dalam upaya memajukan daya saing perekonomian nasional secara berkelanjutan, Pemerintah berkomitmen untuk terus meningkatkan iklim penanaman modal yang kondusif dengan terus mengembangkan kegiatankegiatan ekonomi yang bisa mengubah keunggulan komparatif menjadi keunggulan kompetitif.

Komitmen Pemerintah tersebut, antara lain bertujuan untuk mewujudkan kesejahteraan umum, sebagaimana tercantum dalam tujuan negara dalam Pembukaan Undang-Undang Dasar Negara Republik Indonesia Tahun 1945 (UUD 1945) yang menyebutkan bahwa tujuan didirikan Negara Republik Indonesia, antara lain untuk mewujudkan kesejahteraan umum. Tujuan kesejahteraan umum agar tercapai diperlukan upaya. Salah satu upaya tersebut adalah dengan melaksanakan pembangunan diseluruh bidang kehidupan masyarkat, yang dilaksanakan berorientasi pada pertumbuhan dan pemerataan untuk keadilan bagi seluruh rakyat Indonesia, yang dalam pelaksanaannya membutuhkan pendanaan yang besar. Namun pada sisi lain pemerintah memiliki 
Jurnal Caraka Prabu | Volume 01 | No. 01 | Juni 2017

keterbatasan kapasitas dalam terhadap penanaman modal pendanaan. Untuk mengatasi dibandingkan dengan sistemketerbatasan itu, pemerintah sistem perizinan sebelumnya, memberikan kesempatan kepada para penanam modal (Investor) yang berasal dari dalam negeri maupun di luar negeri untuk menamakan dananya dalam pembangunan untuk mendukung terwujudnya pertumbuhan dan pemerataan ekonomi sehingga pembangunan dapat berkelanjutan dan berkualitas.

Investor dari dalam negeri dan luar negeri, yang menanamkan modalnya tersebut, membutuhkan situasi dan kondisi yang kontributif dan positif untuk pengembangan usahanya. Karena itu, beberapa faktor yang mempengaruhi situasi dan kondisi tersebut, antara lain meliputi, pertama, adanya jaminan hukum dan kepastian hukum. Kedua, meningkatkan kapasitas infrastruktur fisik dan pendukung lainnya yang memadai. Ketiga, Pemerintah mendorong pembangunan sistem Pelayanan Terpadu Satu Pintu (PTSP) di bidang penanaman modal yang lebih efektif dan akomodatif sebagaimana ditindaklanjuti oleh Pemerintah Provinsi Jawa Barat dengan mengundangkan Peraturan Daerah Nomor 3 Tahun 2017 tentang Penyelenggaraan Pelayanan Terpadu Satu Pintu dengan pertimbangan sebagai berikut:

a. bahwa dalam rangka penyelenggaraan pelayanan perizinan terpadu, Pemerintah Daerah Provinsi Jawa Barat telah menetapkan Peraturan Daerah Provinsi Jawa Barat Nomor 7 Tahun 2010 tentang Penyelenggaraan Pelayanan Terpadu;

b. bahwa untuk harmonisasi terhadap ketentuan peraturan perundangundangan dan sinkronisasi terhadap penataan kelembagaan di lingkungan Pemerintah Daerah Provinsi Jawa Barat, perlu dilakukan peninjauan kembali terhadap Peraturan Daerah Provinsi Jawa Barat Nomor 7 
Jurnal Caraka Prabu | Volume 01 | No. 01 | Juni 2017

Tahun 2010 sebagaimana dimaksud pada pertimbangan huruf a;

c. bahwa berdasarkan pertimbangan sebagaimana dimaksud pada huruf a dan huruf $b$, perlu menetapkan Peraturan Daerah Provinsi Jawa Barat tentang Penyelenggaraan Pelayanan Terpadu Satu Pintu;

Pelayanan publik menurut Undang-Undang 25 Tahun 2009 diartikan sebagai kegiatan atau rangkaian kegiatan dalam rangka pemenuhan kebutuhan pelayanan sesuai dengan peraturan perundang-undangan bagi setiap warga negara dan penduduk atas barang, jasa, dan/atau pelayanan administratif yang disediakan oleh penyelenggara pelayanan publik. Pelayanan publik merupakan tanggung jawab pemerintah, maka kualitas pelayanan publik yang diselenggarakan oleh pemerintah ini menjadi salah satu indikator dari kualitas Pemerintahan Daerah.

Provinsi Jawa Barat juga telah mengundangkan Peraturan Daerah Nomor 21 tahun 2011 tentang Penanaman Modal dengan dasar pertimbangan bahwa:

a. bahwa dalam rangka mewujudkan masyarakat adil dan makmur berdasarkan Pancasila dan Undang-Undang Dasar 1945, perlu dilaksanakan pembangunan ekonomi yang berkelanjutan dengan berlandaskan demokrasi ekonomi;

b. bahwa penanaman modal merupakan salah satu faktor penggerak perekonomian Daerah, pembiayaan pembangunan Daerah dan penciptaan lapangan kerja, sehingga perlu diwujudkan kemudahan pelayanan dan iklim penanaman modal yang kondusif dan promotif berdasarkan ekonomi kerakyatan, yang mendorong Usaha Mikro, Kecil, Menengah dan Koperasi untuk meningkatkan realisasi penanaman modal;

c. bahwa berdasarkan pertimbangan pada huruf a dan b, serta untuk memberikan jaminan 
Jurnal Caraka Prabu | Volume 01 | No. 01 | Juni 2017

kepastian hukum, lebih responsif terhadap pelayanan dan perlindungan perkembangan dan tuntutan para penanaman modal, perlu penanam modal. Provinsi Jawa menetapkan Peraturan Daerah Provinsi Jawa Barat tentang Penanaman Modal;

Tujuan penyelenggaraan penanaman modal di Daerah hanya dapat tercapai apabila faktor penunjang yang menghambat iklim penanaman modal dapat diatasi, antara lain melalui perbaikan koordinasi antarinstansi Pemerintah dan Daerah, penciptaan birokrasi yang efisien, kepastian hukum di bidang penanaman modal, biaya ekonomi yang berdaya saing tinggi, serta iklim usaha yang kondusif di bidang ketenagakerjaan dan keamanan berusaha. Dengan perbaikan berbagai faktor penunjang, diharapkan realisasi penanaman modal akan meningkat secara signifikan.

Merujuk pada uraian diatas, salah satu upaya yang dilakukan oleh pemerintah dengan melakukan reformasi dalam bidang hukum investasi, berupa reformasi peraturan perundang-undangan dalam penanaman modal yang
Barat dalam hal ini berencana melakukan perubahan terhadap Peraturan Daerah Nomor 21 tahun 2011 tentang Penanaman Modal. Kebijakan penanaman modal pada zaman reformasi menghasilkan antara lain peraturan perundangundangan yaitu Undang-Undang No. 25 Tahun 2007 tentang Penanaman Modal (UUPM) dan berbagai peraturan perundangan lainnya maupun pelaksanaan UUPM dan peraturan perundangundangan dibidang penanaman modal terus digulirkan oleh pemerintah. Di dalam penyelenggaraan pembangunan memerlukan modal yang cukup besar. Modal tersebut dapat disediakan oleh Pemerintah, Pemerintah Daerah maupun masyarakat luas, terutama pihak swasta. Pembangunan ekonomi yang di dalamnya melibatkan pihak swasta berupa penanaman modal asing maupun dalam negeri mempunyai peranan yang sangat penting dalam kegiatan ekonomi. Hal ini dikarenakan penanaman modal merupakan langkah awal 
Jurnal Caraka Prabu | Volume 01 | No. 01 | Juni 2017

dalam kegiatan produksi.

Pertumbuhan ekonomi suatu negara terkait erat dengan tingkat penanaman modal. Untuk mencapai tingkat pertumbuhan ekonomi yang tinggi diperlukan tingkat penanaman modal yang tinggi.

Peraturan perundang-undangan yang berhubungan dengan UUPM yang dimaksud diatas, antara lain meliputi: (a) Undang-Undang Nomor 39 Tahun 2009 tentang Kawasan Ekonomi Khusus (UU KEK); (b) Peraturan Presiden Nomor 27 Tahun 2009 tentang Pelayanan Terpadu Satu Pintu (PTSP); (c) Peraturan Presiden Nomor 90 Tahun 2007 Tentang Badan Koordinasi Penanaman Modal (BKPM); dan (3) Peraturan Presiden Nomor 16 Tahun 2012 tentang Rencana Umum Penanaman Modal (Perpres No. 16 Tahun 2012).

Rencana Umum Penanaman Modal merupakan dokumen perencanaan yang bersifat jangka panjang sampai dengan tahun 2025. RUPM berfungsi untuk mensinergikan dan mengoperasionalisasikan seluruh kepentingan sektoral terkait, agar tidak terjadi tumpang tindih dalam penetapan prioritas sektor-sektor yang akan dipromosikan. Arah kebijakan penanaman modal sebagaimana yang tercantum dalam Lampiran Perpres No. 16 Tahun 2012 dan diperkuat dengan Peraturan Kepala Badan Koordinasi Penanaman Modal No. 9 Tahun 2012, meliputi 7 (tujuh) elemen utama, yaitu:

1. Perbaikan Iklim Penanaman Modal;

2. Persebaran Penanaman Modal;

3. Fokus Pengembangan Pangan, Infrastruktur, dan Energi;

4. Penanaman Modal yang Berwawasan Lingkungan (green investment);

5. Pemberdayaan Usaha Mikro, Kecil, Menengah, dan Koperasi (UMKMK);

6. Pemberian Fasilitas, Kemudahan, dan Insentif Penanaman Modal; dan

7. Promosi Penanaman Modal. 
Jurnal Caraka Prabu | Volume 01 | No. 01 | Juni 2017

Disamping itu, diatur mengenai adanya keharusan bagi pemerintah Provinsi menyusun rencana umum penanaman modal Provinsi yang mengacu pada Perpres No. 16 Tahun 2012, Rencana Umum Penanaman Modal Provinsi, dan prioritas pengembangan potensi kabupaten/ kota. Penyusunan RUPM Provinsi tersebut, menurut Pasal 4 ayat (4) Perpres No. 16 Tahun 2012 ditetapkan oleh Gubernur. Frasa "ditetapkan" dalam hal ini dimaknai sebagai Peraturan Peraturan Gubernur. Dengan Demikian Rencana Umum Penanaman Modal (RUPM) diatur dalam Peraturan Gubernur Tentang Rencana Umum Penanaman Modal Provinsi Jawa Barat. Subtansi yang akan diatur dalam Peraturan Gubernur tersebut, mengacu pada Pasal 2 Perpres No. 16 Tahun 2012, meliputi:

1. Pendahuluan;

2. Asas dan Tujuan;

3. Visi dan Misi;
4. Arah Kebijakan Penanaman Modal, yang terdiri dari:

a. perbaikan iklim penanaman modal;

b. persebaran penanaman modal;

c. fokus pengembangan pangan, infrastruktur, dan energi;

d. penanaman modal yang berwawasan lingkungan (green investment);

e. pemberdayaan usaha mikro, kecil, menengah, dan koperasi (UMKMK);

f. pemberian fasilitas, kemudahan, dan/ atau insentif penanaman modal; dan

g. promosi penanaman modal.

5. Peta Panduan (Roadmap) Implementasi Rencana Umum Penanaman Modal, yang terdiri dari: 
Jurnal Caraka Prabu | Volume 01 | No. 01 | Juni 2017

a. fase pengembangan Berdasarkan uraian di atas, penanaman modal yang sebelum menyusun RUPM Provinsi relatif mudah dan cepat Jawa Barat yang dituangkan menghasilkan;

b. fase percepatan pembangunan

infrastruktur dan energi;

c. fase pengembangan

industri skala besar; dan

d. fase pengembangan

ekonomi berbasis pengetahuan.

6. Pelaksanaan

Penyusunan RUPM sebagaimana yang diamanahkan Perpres No. 16 Tahun 2012 untuk dilaksanakan oleh Pemerintah Provinsi Jawa Barat seperti yang telah dijelaskan diatas, merupakan dokumen perencanaan penanaman modal jangka panjang, dan berlaku sampai dengan Tahun 2025, dan merupakan bagian integral dari perencanaan sebagaimana yang tercantum dalam Rencana Pembangunan Jangka Panjang (RPJP) Provinsi Jawa Barat dan Rencana Pembangunan Jangka Menengah (RPJM) Provinsi Jawa Barat. Penanaman Modal, terlebih dahulu perlu dilakukan kajian sebagai dasar secara akademik untuk mengevaluasi peraturan daerah sehingga relevan dengan dinamika sosial, politik, ekonomi dan pemerintahan Jawa Barat.

\section{Tujuan Penelitian}

Tujuan penelitian ini yaitu

Berdasarkan identifikasi masalah yang dikemukakan di latar belakang, tujuan penelitian ini meliputi:

1. Merumuskan permasalahan yang dihadapi dalam penanaman modal.

2. Merumuskan alasan pembentukan Rancangan Peraturan Daerah Provinsi Jawa Barat tentang Penanaman Modal sebagai dasar pemecahan masalah terkait penanaman modal di Pemerintah Daerah Provinsi Jawa Barat.

\section{METODE PENELITIAN}


Jurnal Caraka Prabu | Volume 01 | No. 01 | Juni 2017

Metodologi yang akan digunakan untuk menganalisa permasalahan Penyelenggaraan Pengaturan Penanaman Modal Pemerintah Provinsi Jawa Barat, menggunakan pendekatan analisa deskriptif. Dilihat dari permasalahan yang menjadi fenomena dalam penelitian ini, dituntut untuk mampu merumuskan rekomendasi sebagai bahan penyusunan dokumen kebijakan dalam Penyelenggaraan Pengaturan Penanaman Modal Pemerintah Provinsi Jawa Barat. Diharapkan dengan pendekatan analisa deskriptif dapat melahirkan output Penelitian yang sesuai dengan tujuan penelitian.

\section{HASIL DAN PEMBAHASAN}

Dalam rangka terbangunnya keterpaduan dan konsistensi arah perencanaan penanaman modal, dalam penyusunan RUPM, maka Pemerintah Provinsi Jawa Barat memperhatikan 7 (tujuh) arah kebijakan penanaman modal sebagaimana tertuang dalam Perpres Nomor 16 Tahun 2012 tentang Rencana Umum Penanaman Modal, yaitu:

\section{a. Perbaikan Iklim Penanaman Modal}

Iklim penanaman modal merupakan suatu lingkungan kebijakan, institusional dan perilaku, baik kondisi yang ada saat ini maupun kondisi yang diharapkan, yang mempengaruhi tingkat resiko maupun tingkat pengembalian penanaman modal. Iklim penanaman modal ini sangat mempengaruhi keinginan penanam modal (investor) untuk melakukan kegiatan penanaman modal, baik berupa penanaman modal baru maupun perluasan penanaman modal yang telah berjalan. Iklim penanaman modal bersifat dinamis, artinya setiap elemen yang terkandung didalamnya akan mengalami perubahan seiring perubahan dinamika bisnis dan waktu. Selain itu, iklim penanaman modal pula bersifat lokasional, artinya meskipun iklim penanaman modal akan sangat diwarnai oleh situasi dan kondisi perekonomian nasional, namun perbedaan karakteristik masing-masing perekonomian regional dan daerah akan memberi arah penekanan 
Jurnal Caraka Prabu | Volume 01 | No. 01 | Juni 2017

yang berbeda dalam upaya Terpadu Satu Pintu di Bidang perbaikan iklim penanaman modal di Indonesia. ${ }^{1}$

\section{b. Penguatan Kelembagaan Penanaman Modal}

Ketentuan dalam Pasal 26 angka 2 Undang-undang Nomor 25 Tahun 2007 tentang Penanaman Modal (UU PM) secara jelas telah menyebutkan menyebutkan bahwa pelayanan terpadu satu pintu (PTSP) dilakukan oleh lembaga atau instansi yang berwenang dibidang penanaman modal yang mendapat pendelegasian atau pelimpahan wewenang dari lembaga atau instansi yang memiliki kewenangan perizinan dan nonperizinan ditingkat pusat atau lembaga atau instansi yang berwenang mengeluarkan perizinan dan nonperizinan di provinsi atau kabupaten/kota.

Merujuk pada Pasal 26 ayat (3) UU PM ditindaklanjuti dengan Peraturan Presiden Nomor 27 Tahun 2009 Tentang Pelayanan

\footnotetext{
${ }^{1}$ Lampiran Peraturan Kepala BKPM No. 9 Tahun 2012 tentang Pedoman Penyusunan Rencana Umum Penanaman Modal Provinsi dan Rencana Umum Penanaman Modal Kabupaten/Kota.
} angka 4 menyatakan: Pelayanan Terpadu Satu Pintu, yang selanjutnya disingkat PTSP adalah kegiatan penyelenggaraan suatu perizinan dan nonperizinan yang mendapat pendelegasian wewenang dari lembaga atau instansi yang memiliki kewenangan perizinan dan nonperizinan yang proses pengelolaannya dimulai dari tahap permohonan sampai dengan tahap terbitnya dokumen yang dilakukan dalam satu tempat.

Pelayanan Terpadu Satu Pintu, yang selanjutnya disingkat PTSP adalah kegiatan penyelenggaraan suatu perizinan dan nonperizinan yang mendapat pendelegasian atau pelimpahan wewenang dari lembaga atau instansi yang memiliki kewenangan perizinan dan nonperizinan yang proses pengelolaannya dimulai dari tahap permohonan sampai dengan tahap terbitnya dokumen yang dilakukan dalam satu tempat. ${ }^{2}$

2Pasal 1 angka 4 Peraturan Presiden Nomor 27 Tahun 2009 tentang Pelayanan 
Jurnal Caraka Prabu | Volume 01 | No. 01 | Juni 2017

PTSP di bidang penanaman modal bertujuan untuk membantu penanam modal dalam memperoleh kemudahan pelayanan, fasilitas fiskal, dan informasi mengenai penanaman modal, dengan cara mempercepat, menyederhanakan pelayanan, dan meringankan atau menghilangkan biaya pengurusan perizinan dan nonperizinan. ${ }^{3}$

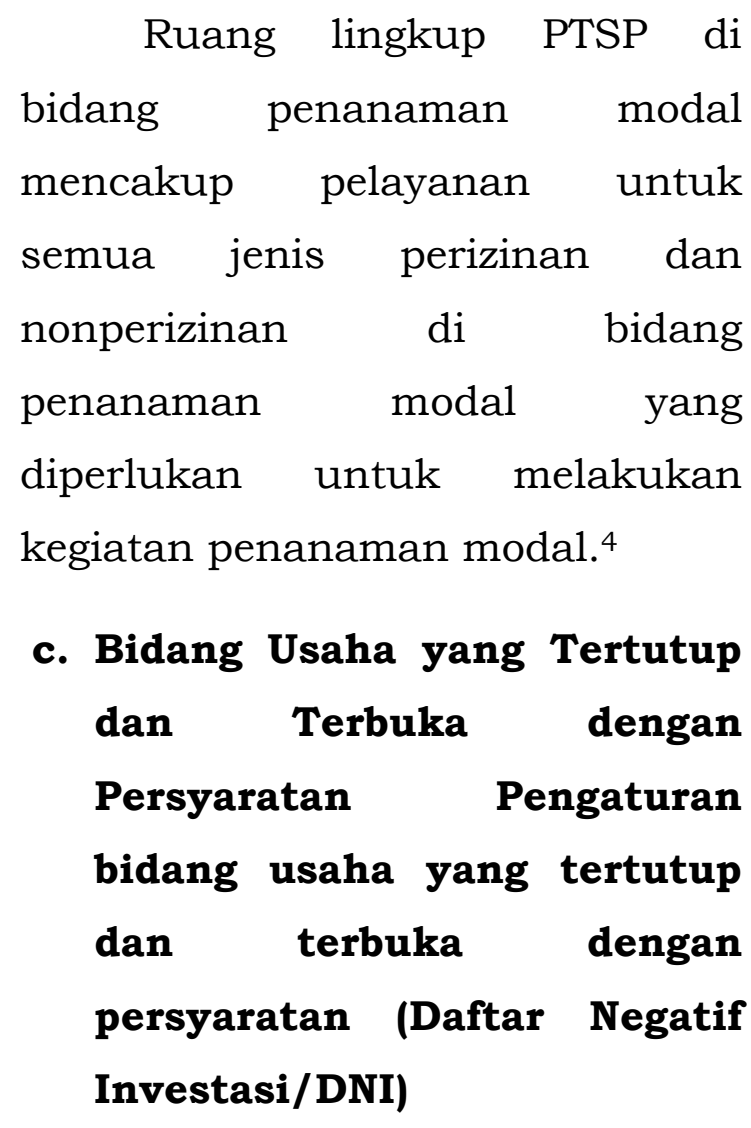

Terpadu Satu Pintu di Bidang Penanaman Modal.

3Pasal 3 Peraturan Presiden Nomor 27 Tahun 2009 tentang Pelayanan Terpadu Satu Pintu di Bidang Penanaman Modal.

4Pasal 4 Peraturan Presiden Nomor 27 Tahun 2009 tentang Pelayanan Terpadu Satu Pintu di Bidang Penanaman Modal.
Secara subtansi UUPM, mengatur bidang-bidang usaha yang dapat diterapkan penanaman modal adalah pertanian, kehutanan, kelautan, industri manufaktur, jasa (termasuk perbankan), dan pertambangan bahwa, pada dasarnya, semua bidang usaha ekonomi dapat diterapkan penanaman modal, kecuali yang memang telah ditentukan oleh perundangundangan sebagai bidang yang tidak boleh dimasuki penanaman modal.

Dalam Pasal 12 UU PM telah ditentukan tiga golongan bidang usaha. Ketiga golongan bidang usaha itu, meliputi: (a) bidang usaha terbuka; (b) bidang usaha tetutup;dan(c) bidang usaha terbuka dengan persyaratan. ${ }^{5}$

Bidang usaha yang terbuka merupakan bidang usaha yang diperbolehkan untuk penanaman modal oleh penanam dalam negeri maupun luar negeri. ${ }^{6}$ Sementara itu, bidang usaha yang tertutup merupakan bidang usaha tertentu

5 Salim H. S. dan Budi Sutrisno, op. cit., hal. 54 .

${ }^{6}$ Ibid 
Jurnal Caraka Prabu | Volume 01 | No. 01 | Juni 2017

yang dilarang diusahakan sebagai kegiatan penanaman modal. ${ }^{7}$

Di dalam Pasal 12 ayat (2) UU PM telah ditentukan daftar bidang usaha yang tertutup bagi penanaman modal, baik untuk investasi domestik maupun investasi asing, yang meliputi: (a) produksi senjata; (b) mesiu; (c) alat peledak; (d) peralatan perang; dan (e) bidang usaha yang secara eksplisit dinyatakan tertutup berdasarkan undangundang.

Ketentuan lebih lanjut Pasal 12 ayat (2) UU PM diatur dalam Peraturan Presiden Nomor 36 Tahun 2010 tentang Daftar Bidang Usaha yang Tertutup dan Daftar Bidang Usaha Terbuka Dengan Persyaratan di Bidang Penanaman Modal. Dalam Lampiran I Peraturan Presiden Nomor 36 Tahun 2010 telah diatur rinci tentang Daftar Bidang Usaha yang Tertutup, terdapat dua puluh daftar bidang usaha yang tertutup, baik untuk investasi domestik maupun investasi asing. Kedua

7Pasal 1 ayat (1) Peraturan Presiden Nomor 36 Tahun 2010 tentang Daftar Bidang Usaha yang Tertutup dan Daftar Bidang Usaha yang Terbuka dengan Persyaratan di Bidang Penanaman Modal. puluh daftar bidang usaha yang tertutup untuk investasi yaitu: ${ }^{8}$

1. Budidaya ganja;

2. Penangkapan spesies ikan yang tercantum dalam Appendix I Convention on International Trade in Endangered Species of Wild Fauna and Flora (CITES);

3. Pemanfaatan (pengambilan) koral/karang dari alam untuk bahan bangunan/kapur/kalsiu $\mathrm{m}$ dan souvenir/perhiasan, serta koral hidup atau koral mati (recent death coral) dari alam;

4. Industri minuman mengandung alkohol (minuman keras, anggur, dan minuman mengandung malt);

8Lampiran I Peraturan Presiden Nomor 36 Tahun 2010, tentang Daftar Bidang Usaha yang Tertutup dan yang Terbuka Dengan Persyaratan di Bidang Penanaman Modal. 
Jurnal Caraka Prabu | Volume 01 | No. 01 | Juni 2017

5. Industri pembuat chlor alkali dengan proses merkuri;

6. Industri bahan kimia yang dapat merusak lingkungan seperti: (a) halon dan lainnya; (b) penta chlorophenol, dichloro diphenyl trichloro elhane (DDT), dieldrin, chlordane, carbon tetra, chloride, methyl chloroform, methyl bromide, chloro fluoro carbon (CFC)

7. Industri bahan kimia schedule I konvensi senjata kimia (sarin, soman, tabun mustard, levisite, ricine, saxitoxin, $V X$, dan lain-lain);

8. Penyediaan dan penyelenggaraan terminal darat;

9. Penyelenggaraan dan pengoperasian jembatan timbang;

10. Penyelenggaraan pengujian tipe kendaraan bermotor;
11. Penyelenggaraan pengujian berkala kendaraan bermotor;

12. Telekomunikasi/sarana bantu navigasi pelayaran;

13. Vassel traffic information system (VTIS);

14. Jasa pemanduan lalu lintas udara;

15. Manejemen dan Penyelenggaraan Stasiun Monitoring Spektrum Frekuensi Radio dan Orbit Satelit;

16. Museum pemerintah;

17. Peninggalan sejarah dan purbakala (candi, keratin, prasasti, bangunan kuno, dan sebagainya);

18. Pemukiman/lingkungan adat;

19. Monument; dan

20. Perjudian/Kasino.

Daftar bidang usaha yang tertutup dalam Peraturan Presiden Nomor 36 Tahun 2010 ini jauh lebih sedikit bila dibandingkan 
Jurnal Caraka Prabu | Volume 01 | No. 01 | Juni 2017

dengan daftar bidang usaha yang dinyatakan tertutup dalam Peraturan Presiden Nomor 111 Tahun 2007, dimana pada Peraturan Presiden Nomor 111 Tahun 2007 terdapat 23 bidang usaha yang dinyatakan terutup. Hal ini dikarenakan terdapat tiga bidang usaha yang dikeluarkan dari daftar bidang usaha yang tertutup, yakni: (a) objek ziarah, seperti: tempat peribadatan, petilasan, dan makam; (b) lembaga penyiaran publik radio dan televisi; dan (c) industri siklamat dan sakarin.

Bidang usaha yang tertutup dapat dimanfaatkan untuk tujuantujuan non komersial seperti, penelitian dan pengembangan dan mendapat persetujuan dari sektor yang bertanggung jawab atas pembinaan bidang usaha tersebut. ${ }^{9}$

\section{c. Persaingan Usaha}

Persaingan usaha yang sehat bertujuan untuk mengendalikan perilaku monopoli, dengan dasar pemikiran bahwa kompetisi atau peraingan usaha

9 Salim H.S. dan Budi Sutrisno, op. cit., hal. 56. adalah baik dan sehat untuk mengefisiensikan dunia usaha sehingga menguntungkan konsumen, karena persaingan diprediksi dapat menekan harga serendah mungkin. ${ }^{10}$

Persaingan juga dapat mengoptimalkan proses prduksi dan distribusi barang dan jasa sehingga iklim usaha menjadi kondusif. Selain itu, Persaingan Usaha yang sehat merupakan konsep bagi keadilan dan kejujuran dalam melakukan hubungan bisnis. Dalam hal ini Negara dengan masyarakat yang ekonominya terbuka terhadap persaingan akan memiliki tingkat harga yang lebih rendah, produk yang lebih baik dan pilihan yang lebih luas bagi konsumennya. Oleh karena itu, sangat diperlukan adanya perlindungan bagi terciptanya persaingan usaha yang sehat di dunia bisnis. ${ }^{11}$

Selain itu, persaingan usaha merupakan faktor penting dari iklim penanaman modal untuk

${ }_{10}$ Agung Sujatmiko, Aspek Yuridis Lisensi Merek dan Persaingan Usaha, April 2008, Jurnal Hukum Pro Justitia, Volume 26, No 2, hlm 94

${ }^{11}$ Ibid 
Jurnal Caraka Prabu | Volume 01 | No. 01 | Juni 2017

mendorong kemajuan ekonomi, maka $^{12}$ :

1. Pemerintah menetapkan pengaturan persaingan usaha yang sehat (level playing field), sehingga menjamin adanya kepastian kesempatan berusaha yang sama di masing-masing pelaku usaha.Dengan demikian, dunia usaha dapat tumbuh dan berkembang secara sehat, serta dapat menghindari pemusatan kekuatan ekonomi pada perorangan atau kelompok tertentu.

2. Pemerintah meningkatkan pengawasan dan penindakan terhadap kegiatan-kegiatan yang bersifat antipersaingan, seperti penetapan syarat perdagangan yang merugikan, pembagian wilayah dagang, dan strategi penetapan harga barang yang mematikan pesaing;

12 Lampiran Peraturan Kepala BKPM No. 9 Tahun 2012 tentang Pedoman Penyusunan Rencana Umum Penanaman Modal Provinsi dan Rencana Umum Penanaman Modal Kabupaten/Kota
3. Lembaga pengawas persaingan usaha yang telah dibentuk Pemerintah terus mengikuti perkembangan terakhir praktek-praktek persaingan usaha, termasuk kompleksitas praktek dan aturan persaingan usaha di negara lain.

Sebagaimana telah dijelaskan diatas, bahwa ketentuan DNI selain merupakan saringan awal kegiatan penanaman modal, juga merupakan salah satu instrumen peraturan perundang-undangan yang digunakan oleh Pemerintah dalam rangka pengaturan persaingan usaha yang sehat di aspek hulu. Untuk itu, mengingat pelaksanaan kegiatan usaha penanaman modal berada di Provinsi Jawa Barat, maka Pemprov Jawa Barat melakukan langkah-langkah pemantauan kegiatan penanaman modal, pembinaan serta pengawasan dalam rangka memastikan pelaksanaan kegiatan penanaman modal sesuai perizinan yang telah diberikan.

\section{d. Hubungan Industrial}


Jurnal Caraka Prabu | Volume 01 | No. 01 | Juni 2017

Dalam Pasal 10 ayat (1) UU PM, disebutkan

bahwa perusahaan penanaman modal dalam memenuhi kebutuhan tenaga kerja harus mengutamakan tenaga kerja warga negara Indonesia. Dengan disebutkan secara eksplisit, dalam pasal ini, maka, diharapkan perusahaan asing atau penanaman modal asing mampu menciptakan lapangan kerja dan memberikan kesejahteraan masyarakat. Menyerap tenaga kerja dalam negeri akan selalu meningkatkan pertumbuhan ekonomi nasional, dengan diberdayakanya tenaga kerja indonesia. Namun demikian menurut Pasal 10 ayat (2) UU PM, disebutkan bahwa perusahaan penanaman modal berhak menggunakan tenaga ahli warga negara asing untuk jabatan dan keahlian tertentu sesuai dengan ketentuan peraturan perundangundangan. Ketentuan tersebut, pada kenyatanya membuat peran tenaga kerja Indonesia berkurang, semua lahan pekerjaan yang strategis ditempati oleh tenaga kerja asing saja, karena cendrung dipercaya oleh perusahaan asing, dan dianggap lebih expert (ahli).
Padahal menrurut Pasal 10 ayat (3) UU PM, disebutkan bahwa perusahaan penanaman modal wajib meningkatkan kompetensi tenaga kerja warga negara Indonesia melalui pelatihan kerja sesuai dengan ketentuan peraturan perundangundangan. Dengan adanya pelatihan kerja ini, maka tenaga kerja Indonesia, dapat menempati posisi-posisi penting yang ada diperusahaan, kemudian diharapkan setelah menempati posisi yang strategis, maka tenaga kerja Indonesia yang telah mempunyai keahlian tersebut mampu membuat lapangan kerja sendiri, sehingga mendorong kesejahteraan. Namun dalam prakteknya, pelatihan kerja yang diberikan oleh perusahaan asing tak lain hanya pelatihan yang bersifat non-strategis, sehingga tidak dapat mengembangkan ilmu yang didapatkan dari pelatihan kerja untuk membuat lapangan kerja baru.

\section{e. Sistem Perpajakan}

Sebagai bagian dari salah satu sisitem perpajakan, diterbitka Peraturan Pemerintah No. 1 Tahun 
Jurnal Caraka Prabu | Volume 01 | No. 01 | Juni 2017

2007 tentang Fasilitas Pajak

Penghasilan untuk Penanaman

Modal di Bidang-Bidang Usaha

Tertentu dan/atau di Daerah

Tertentu. Subtansi Peraturan

Pemerintah tersebut, merupakan penyempurnaan yang berupa perluasan cakupan bidang-bidang tertentu dan/atau daerah tertentu yang memperoleh fasilitas.

Ketentuan dalam Pasal 3 dari Peraturan Pemerintah Nomor 45 Tahun 2008 tentang Pedoman Pemberian Insentif dan Pemberian Kemudahan Penanaman Modal di Daerah tersebut berisi antara lain pemberian insentif yang bentuknya berbagai macam, antara lain: pengurangan, keringanan atau pembebasan pajak daerah; pengurangan, keringanan, atau pembebasan retribusi daerah; pemberian dana stimulan; dan/atau pemberian bantuan modal.

Sementara itu, pemberian kemudahan bentuknya bisa berupa: penyediaan data dan informasi peluang penanam modal; penyediaan sarana dan prasarana; penyediaan lahan atau lokasi; pemberian bantuan teknis; dan/atau percepatan pemberian perizinan.

Kemudian Pasal 5 Peraturan Pemerintah Nomor 45 Tahun 2008 tentang Pedoman Pemberian Insentif dan Pemberian Kemudahan Penanaman Modal di Daerah mengemukakan bahwa pemberian insentif dan pemberian kemudahan diberikan kepada penanaman modal yang sekurangkurangnya memenuhi salah satu kriteria sebagai berikut: memberikan kontribusi bagi peningkatan pendapatan; menyerap tenaga kerja lokal; (3) menggunakan sebagian besar sumber daya lokal; memberikan kontribusi bagi peningkatan pelayanan publik; (5) memberikan kontribusi dalam peningkatan Produk Domestik Regional Bruto (PDRB); (6) berwawasan lingkungan dan berkelanjutan; (7) termasuk alih teknologi; (8) melakukan industri pionir; (8) berada di daerah terpencil, daerah tertinggal, atau daerah perbatasan; melaksanakan kegiatan penelitian, pengembangan, dan inovasi; (10) bermitra dengan usaha mikro, 
Jurnal Caraka Prabu | Volume 01 | No. 01 | Juni 2017

kecil, menengah, atau koperasi;

atau (11) industri yang menggunakan barang modal, mesin, atau peralatan yang diproduksi di dalam negeri.

$\begin{array}{lll}\text { Selanjutnya } & \text { Pasal } & 7\end{array}$

Peraturan Pemerintah Nomor 45

Tahun 2008 tentang Pedoman Pemberian Insentif dan Pemberian Kemudahan Penanaman Modal di Daerah mengungkapkan bahwa ketentuan pemberian insentif dan/atau pemberian kemudahan penanaman modal di daerah diatur dengan Perda yang sekurang-kurangnya memuat antara lain: (1) tata cara memperoleh pemberian insentif dan pemberian kemudahan; (2) kriteria pemberian insentif dan pemberian kemudahan; (3) dasar penilaian pemberian insentif dan pemberian kemudahan; (4) jenis usaha atau kegiatan penanaman modal yang diprioritaskan memperoleh insentif dan kemudahan; dan (5) bentukbentuk insentif dan kemudahan yang dapat diberikan dan 6) pengaturan pembinaan dan pengawasan.

\section{f. Persebaran Penanaman Modal}

Persebaran

penanaman modal selain pengembangan penanaman modal yang fokus menurut bidang atau sektor unggulan/prioritas di Provinsi Jawa Barat, Pemerintah provinsi Jawa Barat perlu merumuskan strategi dan kebijakan dalam upaya mendorong pemerataan pembangunan ekonomi melalui penyebaran kegiatan usaha penanaman modal berdasarkan Rencana Tata Ruang Wilayah (RTRW) provinsi Jawa Barat.

Arah kebijakan pemerintah daerah Jawa Barat untuk mendorong persebaran penanaman modal apabila memenuhi kriteria investor yang akan mendapat fasilitas penanaman modal ditentukan dalam Pasal 18 ayat (3) UU PM yang akan mendapat fasilitas penanaman modal. Kriteria itu meliputi: ${ }^{13}$
a. Menyerap banyak tenaga kerja;

b. Termasuk skala prioritas tinggi; 
Jurnal Caraka Prabu | Volume 01 | No. 01 | Juni 2017

c. Termasuk

pembangunan

infrastruktur;

d. Melakukan

alih teknologi;

e. Melakukan industri pionir;

f. Berada di daerah terpencil, daerah tertinggal, daerah perbatasan, atau daerah lain yang dianggap perlu;

g. Menjaga kelestarian lingkungan hidup;

h. Melaksanakan kegiatan penelitian, pengembangan dan inovasi;

i. Bermitra dengan usaha mikro, kecil, menengah, atau koperasi; atau

j. Industri yang menggunakan barang modal atau mesin atau peralatan yang diproduksi di dalam negeri.

\section{f. Penanaman Modal yang Berwawasan Lingkungan (Green Investment)}

Ketentuan dalam Pasal 22 ayat (4) UU PM merupakan ketentuan penting karena terdapat keterkaitan antara penanaman modal dengan lingkungan hidup. Keterkaitan tersebut, bermakna bahwa penanaman modal atau investasi harus dihentikan jika ternyata mengabaikan kelestarian dan kesuburan tanah serta menyebabkan kerusakan lingkungan hidup. Penanaman modal yang berwawasan lingkungan (Green Investment) Kebijakan Energi Nasional sebagaimana diatur dalam Perpres Nomor 5 Tahun 2006, telah mengamanatkan peningkatan penggunaan energi baru dan terbarukan menjadi lebih dari 80\% pada tahun 2025 .

Arah kebijakan penanaman modal yang berwawasan lingkungan (green investment) di Jawa Barat adalah:

a. Perlunya bersinergi dengan kebijakan dan program 
Jurnal Caraka Prabu | Volume 01 | No. 01 | Juni 2017

pembangunan

lingkungan hidup,

khususnya program

pengurangan emisi

gas transportasi, dan

limbah;

b. Pengembangan sektorsektor prioritas dan teknologi yang ramah lingkungan;

c. Pengembangan

ekonomi hijau (green economy);

d. Pemberian fasilitas, kemudahan dan/atau insentif penanaman modal diberikan kepada penanaman modal yang mendorong upayaupaya pelestarian lingkungan hidup termasuk pencegahan pencemaran, pengurangan pencemaran lingkungan;

e. Peningkatan penggunaan teknologi yang ramah lingkungan yang terintegras;

f. Pengembangan

wilayah yang memperhatikan tata ruang dan kemampuan atau daya dukung lingkungan. Pemda Jabar bekerjasama dengan pelaku usaha mendorong upaya untuk lebih membuka kesempatan

munculnya kegiatan penanaman modal di sektor pionir yang memperkenalkan teknologi baru, ramah energi dan lingkungan, mengedepankan inovasi dan penelitian dan pengembangan dalam rangka upaya penemuan teknologi baru yang ramah lingkungan.

g. Pemberdayaan Usaha Mikro, Kecil, Menengah, dan Koperasi

Sektor Usaha Mikro, Kecil, Menengah, dan Koperasi yang 
merupakan salah satu penggerak penting dalam perekonomian Jawa Barat serta penyedia lapangan kerja terbesar, tetapi masih dihadapkan pada masalahmasalah klasik seperti infrastruktur, perizinan, dan pembiayaan. Ketiga hal tersebut membuat sektor usaha mikro, kecil, menengah, dan koperasi semakin lemahnya daya saing. Belum lagi akan menghadapi MEA pada akhir tahun 2015 .

Wilayah yang secara tradisional menjadi ikon UMKM seperti Cigondewah, Cihampels, Cibaduyut kota Bandung provinsi Jawa Barat dan lain sebagainya; saat ini sudah mulai meredup. Lemahnya aksesibilitas mereka terhadap sumber pembiayaan juga membuat mereka harus terperosok pada dana reternir. Saya yakin pemerintah propinsi dan Bank Indonesia sudah tahu jalan keluarnya, yang harus segera dilakukan adalah melaksanakannya dalam bentuk kebijakan yang berfihak, dan koperasi seyogyanya memiliki posisi strategis dari skema yang dibuat dalam keberpihakan itu. ${ }^{14}$

Berkaitan dengan itu penting artinya, membangun linkage usaha mikro, kecil, menengah, dan koperasi dengan usaha besar, mendukung terlaksananya sektor riil yang sehat ditingkatan akar rumput, mengentaskan kemiskinan melalui penguatan daya beli yang berkeadilan, penguataan kelembagaan ekonomi bentuk koperasi sebagai bagian dari penguatan daya saing usaha mikro, kecil, menengah, dan koperasi dan percepatan pembangunan ekonomi daerah, bangun ekonomi pedesaan secara efektif melalui pengamanan mata rantai usaha mereka, dan perkuat balai-balai latihan kerja agar Jawa Barat menjadi pemasok tenaga kerja terampil yang mampu

14 Rully Indrawan, Tantangan Ekonomi Bagi Gubernur Terpilih, (makalah) diakses dari

http://www.google.com/url?sa=t\&rct=j\&q $=\&$ esrc $=$ s\&source $=$ web\&cd $=8 \&$ ved $=0 \mathrm{CGg}$ QFjAH\&url=http\%3A\%2F\%2Frullyindraw an.files.wordpress.com $\% 2 \mathrm{~F} 2013 \% 2 \mathrm{~F} 03 \% 2$ Ftantangan-ekonomi-bagi-gubernur terpilih.docx\&ei=EMI9Uey9N4vRrQeWnY HgAw\&usg=AFQjCNEizZfFUnawnvwtE5J1 KNKoxJ8NHA\&bvm=bv.43287494,d.bmk, tanggal 11 maret 2013, Pukul 18.53 Wib 
Jurnal Caraka Prabu | Volume 01 | No. 01 | Juni 2017

menciptakan lapangan kerja sendiri.

Penguatan ekonomi akar rumput menjadi penting karena dua alasan strategis, yakni, pertama, alasan sosiologis yakni perlu dihindari masyarakat Jawa Barat menjadi penonton dalam pertumbuhan ekonomi yang tinggi. dan kedua, alasan ekonomi, yakni senyatanya masalah utama Jawa Barat saat ini, juga masalah nasional, adalah tingginya angka kesenjangan pendapatan yang tinggi. 15

\section{h. Pemberian Fasilitas, Kemudahan, dan Insentif Penanaman Modal}

Selain itu, pada tahun yang sama pemerintah menerbitkan Peraturan Pemerintah No. 1 Tahun 2007 tentang Fasilitas Pajak Penghasilan untuk Penanaman Modal di Bidang-Bidang Usaha Tertentu dan/atau di Daerah Tertentu. Subtansi Peraturan Pemerintah tersebut, merupakan penyempurnaan yang berupa perluasan cakupan bidang-bidang

${ }^{15}$ Ibid tertentu dan/atau daerah tertentu yang memperoleh fasilitas.

Ketentuan dalam Pasal 3 dari Peraturan Pemerintah Nomor 45 Tahun 2008 tentang Pedoman Pemberian Insentif dan Pemberian Kemudahan Penanaman Modal di Daerah tersebut berisi antara lain pemberian insentif yang bentuknya berbagai macam, antara lain: pengurangan, keringanan atau pembebasan pajak daerah; pengurangan, keringanan, atau pembebasan retribusi daerah; pemberian dana stimulan; dan/atau pemberian bantuan modal.

Sementara itu, pemberian kemudahan bentuknya bisa berupa: penyediaan data dan informasi peluang penanam modal; penyediaan sarana dan prasarana; penyediaan lahan atau lokasi; pemberian bantuan teknis; dan/atau percepatan pemberian perizinan.

Kemudian Pasal 5 Peraturan Pemerintah Nomor 45 Tahun 2008 tentang Pedoman Pemberian Insentif dan Pemberian Kemudahan Penanaman Modal di Daerah mengemukakan bahwa 
pemberian insentif dan pemberian kemudahan diberikan kepada penanaman modal yang sekurangkurangnya memenuhi salah satu kriteria sebagai berikut: memberikan kontribusi bagi peningkatan pendapatan; menyerap tenaga kerja lokal; (3) menggunakan sebagian besar sumber daya lokal; memberikan kontribusi bagi peningkatan pelayanan publik; (5) memberikan kontribusi dalam peningkatan Produk Domestik Regional Bruto (PDRB); (6) berwawasan lingkungan dan berkelanjutan; (7) termasuk alih teknologi; (8) melakukan industri pionir; (8) berada di daerah terpencil, daerah tertinggal, atau daerah perbatasan; melaksanakan kegiatan penelitian, pengembangan, dan inovasi; (10) bermitra dengan usaha mikro, kecil, menengah, atau koperasi; atau (11) industri yang menggunakan barang modal, mesin, atau peralatan yang diproduksi di dalam negeri.

\section{i. Promosi Penanaman Modal}

Promosi dapat diartikan sebagai salah satu mata rantai sistem pemasaran, merupakan kegiatan komunikasi kepada target market yaitu potential investor, potential buyer dan potential tourist bagi pariwisata, yang dilakukan dalam dan di luar negeri.

Bagi Pemerintah Daerah, promosi sebagai instrumen pembangunan, yang pelaksanaannya oleh lembaga yang merepresentasikan pemerintah daerah. Promosi Pemerintah Daerah, adalah suatu aspek dalam bauran pemasaran, berfungsi sebagai sarana komunikasi dari OPD dan pemangku kepentingan investasi dengan target market, yang dalam konteks ini adalah potential investor, potential buyer dan potential tourist bagi pariwisata, di dalam dan di luar negeri.

Kegiatan promosi dapat dilaksanakan secara langsung dan atau menggunakan media seperti memanfaatkan kemajuan teknologi (teknologi informasi) seperti website, blog khusus, milis email dan melalui media promo yang dikemas dalam bentuk $\mathrm{CD}$, film atau media lainnya seperti koran, majalah, tabloid, televisi dan radio. 
Jurnal Caraka Prabu | Volume 01 | No. 01 | Juni 2017

Selain menggunakan media, promosi pada umumnya sering dilakukan secara langsung melalui:
a. Kegiatan pameran (exhibition);

$\begin{array}{ll}\text { b. Penggunaan } & \text { sarana } \\ \text { (tempat), } & \text { seperti }\end{array}$ kantor perwakilan promosi dan pemasaran;

c. Kegiatan pengiriman \& atau penerimaan misi (dagang, investasi, wisatawan); dan
d. Kerjasama dengan lembaga promosi (nasional/internasiona 1)

Pada prinsipnya setiap Organisasi Perangkat Pemda Jabar dapat melaksanakan promosi baik secara langsung maupun tidak langsung, dengan memperhatikan ketentuan perundang-undangan yang berlaku dan target serta sasaran pembangunan yang telah ditetapkan dalam Peraturan Daerah Provinsi Jawa Barat Nomor 9 Tahun 2008 tentang Rencana Pembangunan Jangka Panjang
(RPJP) Daerah Provinsi Jawa Barat Tahun 2005-2025 sebagaimana telah diubah dengan Peraturan Daerah Provinsi Jawa Barat Nomor 24 Tahun 2010 tentang Perubahan atas Peraturan Daerah Provinsi Jawa Barat Nomor 9 Tahun 2008 tentang Rencana Pembangunan Jangka Panjang (RPJP) Daerah Provinsi Jawa Barat Tahun 20052025. Dan melalui Peraturan Daerah Provinsi Jawa Barat Nomor 8 Tahun 2017 Tentang Perubahan Atas Peraturan Daerah Provinsi Jawa Barat Nomor 25 Tahun 2013 Tentang Rencana Pembangunan Jangka Menengah Daerah Provinsi Jawa Barat Tahun 2013-2018.

\section{KESIMPULAN}

Dari uraian sebelumnya dan indikator-indikator kajian tentang Penanaman Modal di Provinsi Jawa Barat, dapat disimpulkan sebagai berikut:

a. Keberadaan Peraturan Daerah tentang Penanaman Modal di Provinsi Jawa Barat merupakan landasan hukum bagi Pemerintah provinsi Jawa Barat dalam 
Jurnal Caraka Prabu | Volume 01 | No. 01 | Juni 2017

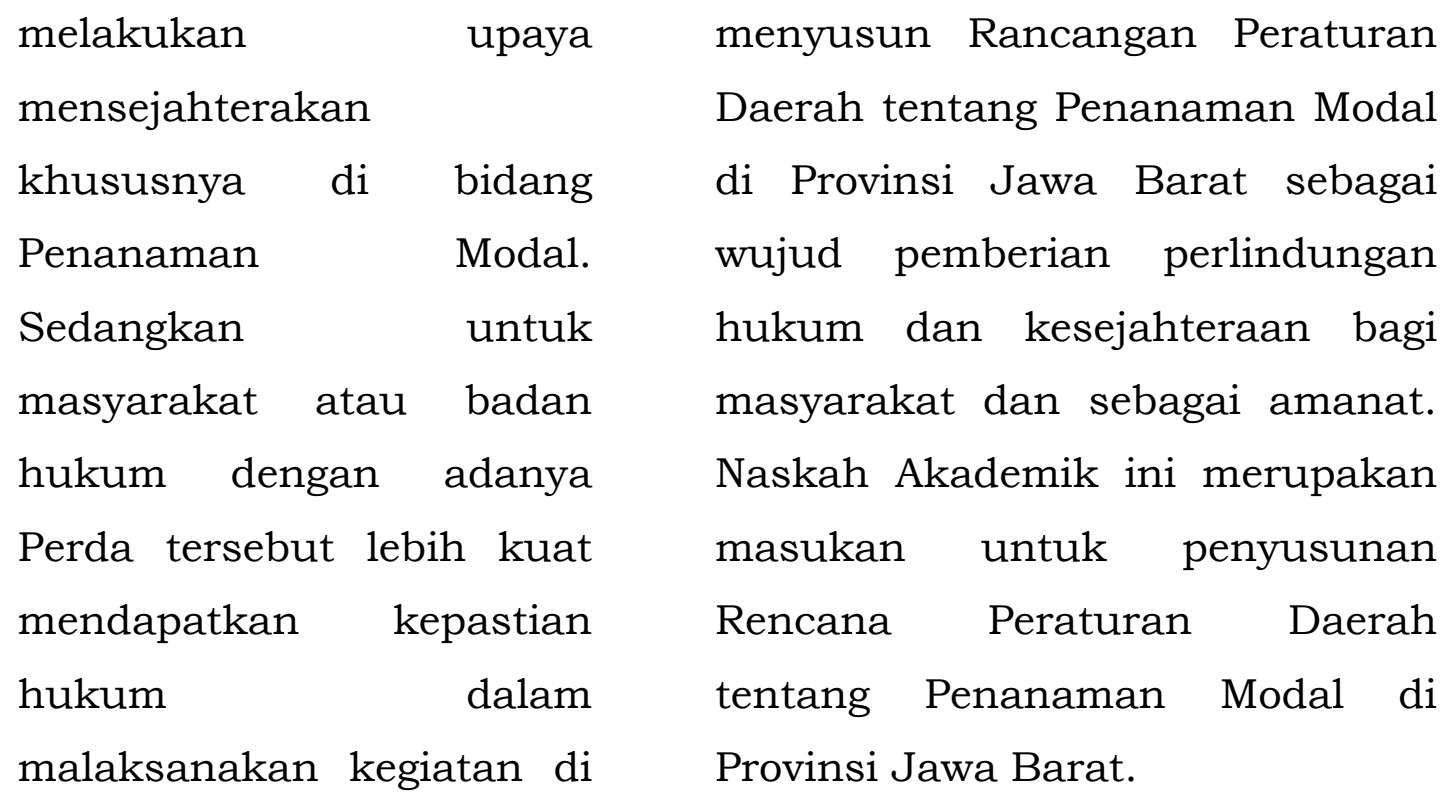

bidang Penanaman Modal.

b. Peraturan Daerah tentang Penanaman Modal di Provinsi Jawa Barat merupakan amanat

Undang-Undang

c. Materi muatan dari Rancangan Peraturan Daerah tentang Penanaman Modal di Provinsi Jawa Barat mengatur secara jelas dan tegas tentang penanaman modal.

\section{REKOMENDASI}

Berdasarkan uraian dan kesimpulan di atas, dapat dirokemendasikan kepada Pemerintah Daerah dan/atau unsur legislatif baik secara bersama maupun sendiri-sendiri berkewajiban untuk segera

\section{DAFTAR PUSTAKA}

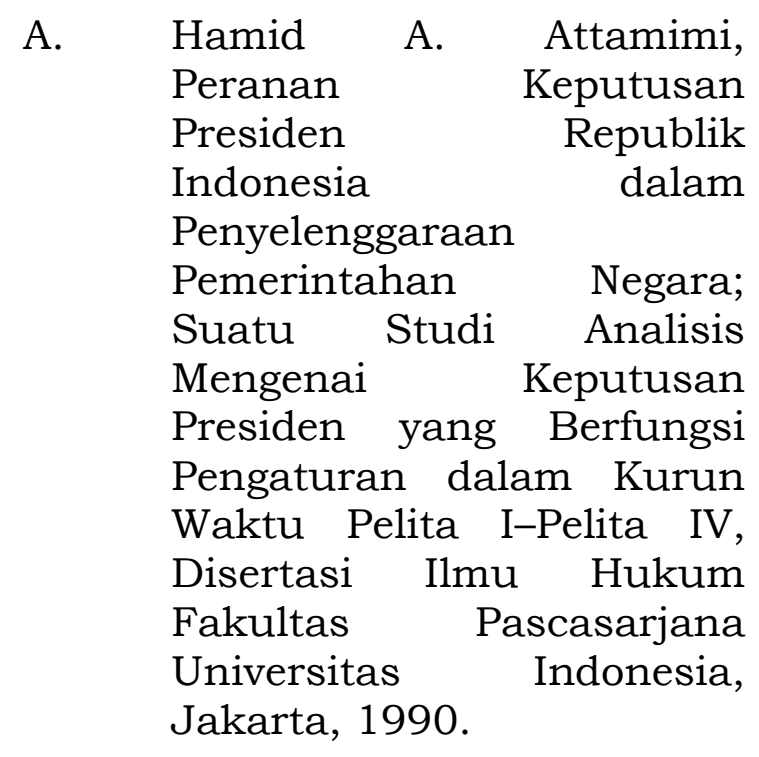

Achmad Ali, Menguak Tabir Hukum (Suatu Kajian Filosofis dan Sosiologis), Gunung Agung, Jakarta, 2002.

Amiruddin dan Zainal Asikin, Pengantar Metode Penelitian Hukum , PT. Raja Grafindo persada, Jakarta: 2006.
A.M. Stroink dalam Abdul Rasyid Thalib, Wewenang Mahkamah Konstitusi dan 
Aplikasinya dalam Sistem Ketatanegaraan Republik Indonesia, Bandung: Citra Aditya Bakti, 2006.

Ateng Syafrudin, Menuju
Penyelenggaraan
Pemerintahan Negara yang
Bersih dan Bertanggung
Jawab, Jurnal Pro Justisia
Edisi IV, Bandung,
Universitas Parahyangan,
2000.

Bagir Manan, Dasar-Dasar Perundang-undangan Indonesia. IND-HILL.CO, Jakarta, 1992.

Bambang Sunggono, Metodologi Penelitian Hukum, PT. Raja Grafindo Persada, Jakarta, 1997.

Bambang Waluyo, Metode Penelitian Hukum, Sinar Grafika, Jakarta, 1998.

BR. Atre, Legislative Drafting: Principles and Techniques, Universal Law Publishing Co., 2001.

Budiman NPD, Ilmu Pengantar Perundang-Undangan UII press Yogyakarta, 2005.

Cecep Sucipto, SKM, M.Sc. Teknologi Pengolahan Daur Ulang Sampah, Gosyen Publishing, Yogyakarta, 2012.

Damanhuri, Enri. Diktat Pengolahan Sampah, Program Studi Teknik Lingkungan : Institut Teknologi Bandung. 2010.

Departemen Pendidikan Nasional, Kamus Besar Bahasa Indonesia, Edisi III, Balai Pustaka, Jakarta, 2002.

\begin{tabular}{|c|}
\hline $\begin{array}{lrr}\text { an, D, } & \text { Kajian } & \text { Yurüfis } \\
\text { Peraturan Daerah Kota } \\
\text { Padang Dalam Upaya } \\
\text { Mengrrangi KKN Fakultas } \\
\text { Hukum } \\
\text { Andalas dalam jursitas } \\
\text { Ilmiah Tambun, Vol. VIII, } \\
\text { No.3, September-Desember } \\
\text { 2009 } \\
\text { http://isjd.pdii.lipi.go.id/ad } \\
\text { min/jurnal/8309483494.p } \\
\text { df. }\end{array}$ \\
\hline
\end{tabular}

Hamid S. Attamini, Perbedaan Antara Peraturan Perundang-Undangan dan Peraturan Kebijakan, Makalah pada Pidato Dies Natalis PTIK Ke-46, Jakarta 17 Juni 1992.

Henry Campbell Black, Black"s Law Dictionary, Amerika Serikat: West Publishing Co., 1978.

Idrus A. Paturusi, dkk. Hasil Penelitian Esensi Dan Urgensitas Peraturan Daerah Dalam Pelaksanaan Otonomi Daerah, DPD RI dan Universitas Hasanuddin, 2009.

Jimly Asshiddiqie, Perihal UndangUndang, Rajawali Pers, Jakarta, 2006.

Kelsen, Hans, General Theory of Law and State, New York, Russell \& Russell, 1945

Mahfud M.D, Membangun Politik Hukum, Menegakkan Konstitusi, Jakarta: 2006

Mardiasmo. Otonomi dan Manajemen Keuangan Daerah. Yogyakarta: Andi, 2002.

Maria Farida Indrati Soeprapto, Ilmu Perundang-Undangan, 
Yogyakarta, Kanisius, 1998.

Markus Lukman, Eksistensi Peraturan Kebijakan Dalam Bidang Perencanaan dan Pelaksanaan Rencana Pembangunan di Daerah Serta Dampaknya Terhadap Pembangunan Materi Hukum Tertulis Nasional, (disertasi), Pascasarjana Universitas Padjadjaran, Bandung, 1997.

Peter Mahmud Marzuki, Penelitian Hukum. Prenada Media, Jakarta, 2005.

Philipus M. Hadjon, Tentang Wewenang, (Makalah), Universitas Airlangga, Surabaya, tanpa tahun.

Purnadi Purbacaraka dan Soerjono Soekanto, Perihal Kaedah Hukum, Cetakan Keenam, Citra Aditya Bakti, Bandung, 1993.

Ridwan HR, Hukum Administrasi Negara, Raja Grafindo Persada, Jakarta, 2008.

Rosyidi Ranggawidjaja dikutip oleh Soimin, Pembentkan Peraturan Negara Di Indonesia, 2010.

Saafroedin Bahar, Ananda B. Kusuma, dan Nannie Hudawati (peny.), Risalah Sidang Badan Penyelidik Usaha-Usaha Persiapan Kemerdekaan (BPUPKI) Panitia Persiapan Kemerdekaan Indonesia (PPKI) 28 Mei 1945 - 22 Agustus 1945, (Jakarta: Sekretariat Negara Republik Indonesia, 1995.
Satjipto Rahardjo, Ilmu Hukum, Bandung: Alumni, 1996.

Salim HS dan Erlies Septiana Nurbani, Penerapan Teori Hukum Pada Penelitian dan Disertasi, Rajawali Pers, cetakan ke-2, Jakarta, 2013.

SF. Marbun dan Moh. Mahfud, Pokok-Pokok Hukurn Administrasi Negara, Yogyakarta, Liberty, 1987.

SNI 19-2454-2002, Tata Cara Operasional Pengolahan Sampah Perkotaan, Badan Standarisasi Nasional Indonesia, 2002.

Soetandyo Wignjosoebroto, Hukum, Paradigma Metode dan Dinamika Masalahnya, Editor ,Ifdhal Kasim et.al., Elsam dan Huma, Jakarta, 2002.

Soerjono Soekanto, Sri Mamudji, Penelitian Hukum Normatif, Raja Grafindo Persada, Jakarta, 2004.

Soerjono Soekanto, Pengantar Penelitian Hukum UI Press, Jakarta, 1986,

Sudikno Mertokusumo, Mengenal Hukum, Liberty, Yogyakarta, 1991.

W. Riawan Tjandra dan Kresno Budi Harsono, Legislatif Drafting Teori dan Teknik Pembuatan Peraturan Daerah, Yogyakarta: Universitas Atmajaya, 2009.

Yuliandri, Asas-azas Pembentukan Peraturan PerundangUndangan yang Baik; Gagasan Pembentukan 
Jurnal Caraka Prabu | Volume 01 | No. 01 | Juni 2017

Undang-undang

Berkelanjutan,

RajaGrafindo

Jakarta, 2009.

Yusriyadi. TebaranPemikiran Kritis

Hukum dan Masyarakat.
Surya Pena Gemilang. Malang, 2010.

Zainuddin Ali, Sosiologi Hukum, Cetakan Ketiga, Sinar

Grafika, Jakarta, 2008 